\title{
TALKING PARTS, TALKING BACK: FLESHING OUT LINGUISTIC CITIZENSHIP
}

\section{PARTES DO CORPO FALANTES E AGENCIAMENTOS: DANDO CORPO À CIDADANIA LINGUÍSTICA}

\author{
Christopher Stroud ${ }^{1}$ \\ Quentin Williams ${ }^{2}$ \\ Ndimphiwe Bontiya ${ }^{3}$ \\ Janine Harry ${ }^{4}$ \\ Koki Kapa ${ }^{5}$ \\ Jaclisse Mayoma ${ }^{6}$ \\ Sibonile Mpendukana ${ }^{7}$ \\ Amiena Peck ${ }^{8}$ \\ Jason Richardson ${ }^{9}$ \\ Shanleigh Roux ${ }^{10}$
}

1. Centre for Multilingualism and Diversities Research (CMDR), University of the Western Cape (UWC), South Africa/Center for Bilingualism Research, Stockholm University (SU), Stockholm, Sweden, cstroud@uwc.ac.za

Orcid: https://orcid.org/0000-0001-7692-0362

2. Department of Linguistics/Centre for Multilingualism and Diversities Research (CMDR), University of the Western Cape (UWC), South Africa, qwilliams@uwc.ac.za

Orcid: https://orcid.org/0000-0003-4154-4920

3. Department of Linguistics/Centre for Multilingualism and Diversities Research (CMDR), University of the Western Cape (UWC), South Africa, 3409028@myuwc.ac.za

Orcid: https://orcid.org/0000-0001-9137-5489

4. Department of Linguistics/Centre for Multilingualism and Diversities Research (CMDR), University of the Western Cape (UWC), South Africa, janineharry90@gmail.com Orcid: https://orcid.org/0000-0003-0582-0705

5. University of Witwatersrand, Johannesburg, South Africa, koki.kapa@gmail.com Orcid: https://orcid.org/0000-0002-1703-2397

6. Department of Linguistics/Centre for Multilingualism and Diversities Research (CMDR), University of the Western Cape (UWC), South Africa, j.1.mayoma@gmail.com Orcid: https://orcid.org/0000-0002-4021-0921

7. Linguistics Section, University of Cape Town, South Africa, sibonile.mpendukana@uct.ac.za Orcid: https://orcid.org/0000-0002-0701-3846

8. Department of Linguistics/Centre for Multilingualism and Diversities Research (CMDR), University of the Western Cape (UWC), South Africa, apeck@uwc.ac.za Orcid: https://orcid.org/0000-0002-1261-1998

9. Department of Linguistics/Centre for Multilingualism and Diversities Research (CMDR), University of the Western Cape (UWC), South Africa, jrichardson@uwc.ac.za Orcid: https://orcid.org/0000-0003-2448-8963

10. Department of Linguistics/Centre for Multilingualism and Diversities Research (CMDR), University of the Western Cape (UWC), South Africa, shroux@uwc.ac.za Orcid: https://orcid.org/0000-0002-1323-4274 


\begin{abstract}
One of the greatest challenges of our times is that of lack of voice for abused bodies. These are the bodies of children and men and women who have inherited the brutalities of colonialism, plantation servitude and slavery and now re-live these miseries in the belly of a rampant global neoliberal and patriarchal capitalism. They are the racialized, sexualized, genderized and godless bodies that first took form in coloniality-modernity in conjunction with the emergence of MAN, the White, rational, disembodied male as HUMAN. They retain their shape today through technologies of vulnerability, with which the manufactured lack of voice works in dynamic synergy. This is particularly the case for South Africa, with its tender histories and distraught presents, raw emotion and sore vulnerabilities of racialized and neoliberal patriarchy. In this paper, we suggest that vulnerability, beyond its potentially devastating effect on souls and livelihoods, may also be a productive site for the articulation of alternative, and habitually silenced voices. In this regard, we explore how a focus on acts of Linguistic Citizenship may orientate thinking on voice and agency to different sites of the body, as well as allow insight into the complex technologies and practices of vulnerability.
\end{abstract} Keywords: voice, bodies, vulnerability, linguistic citizenship, South Africa.

\title{
RESUMO
}

Um dos maiores desafios do nosso tempo é o da falta de voz para corpos maltratados. São os corpos de crianças e homens e mulheres que herdaram as brutalidades do colonialismo, da servidão das plantações e da escravatura, e agora revivem essas misérias no ventre de um capitalismo global neoliberal e patriarcal. São os corpos racializados, sexualizados, generificados e sem deus que primeiro tomaram forma na colonialidade-modernidade em conjunto com a emergência do HOMEM, o macho branco, racional, sem corpo, como HUMANO. Mantêm hoje a sua forma através de tecnologias de vulnerabilidade, com as quais a falta de voz fabricada funciona em sinergia dinâmica. Este é particularmente o caso da África do Sul, com as suas histórias ternas e presentes perturbados, emoção crua e vulnerabilidades dolorosas do patriarcado racializado e neoliberal. Neste artigo, sugerimos que a vulnerabilidade, para além do seu efeito potencialmente devastador nas almas e meios de vida, pode também ser um local produtivo para a articulação de vozes alternativas e habitualmente silenciadas. A este respeito, exploramos a forma como um enfoque em atos de cidadania linguística pode orientar o pensamento sobre voz e agência para diferentes locais do corpo, bem como permitir uma visão das complexas tecnologias e práticas de vulnerabilidade. Palavras-chave: voz, corpos, vulnerabilidade, cidadania linguística, África do Sul.

\section{INTRODUCTION}

One of the greatest challenges of our times is that of lack of voice for abused bodies. These are the bodies of children and men and women who have inherited the brutalities of colonialism, plantation servitude and slavery and now re-live these miseries in the belly of a rampant global neoliberal and patriarchal capitalism. They are the racialized, sexualized, genderized and godless bodies that first took form in coloniality-modernity in conjunction with the emergence of MAN (Wynter, 2003), the White, rational, disembodied male as HUMAN. They retain their shape today 
through technologies of vulnerability, with which the manufactured lack of voice works in dynamic synergy. This is particularly the case for South Africa, with its tender histories and distraught presents, raw emotion and sore vulnerabilities of racialized and neoliberal patriarchy.

At the moment of post-apartheid and with the ushering in of the new dispensation, South Africa began to experience a Fanonian nightmare: True to Fanon's prediction, the structure and institutions inherited from colonialism and apartheid, now predominantly inhabited by revolutionary Black bodies, continued their reproduction of historical inequity. Corruption, nepotism and looting of public resources in an unprecedented project of so-called 'state capture' became the modus operandi of a political elite intent on enriching itself at any cost. In its wake, it left behind the collapse of state owned enterprise and social services, a devastated economy, and the material and psychological impoverishment of a once hopeful people. Crime rates accelerated, together with unprecedented levels of femicide and widespread general violence; racial antagonisms are once again on the rise, and a seeping malaise across society is crippling dreams of better futures. Shockingly, although perhaps not surprisingly, the COVID-19 lockdown offered abundant opportunity for tender theft of scarce and vital resources in a cynical chase for profit, sadly accompanied by a militarized management of pandemic proportions, with the killing, rather than care, of those who literally 'stepped out of line'.

Concurrently with this spiral of despair, new movements, at all levels of society have attempted to mobilize counter-hegemonic forces. So-called 'service delivery protests, where towsnhip and shack dwellers demand (sometimes violently) basic provision of services such as water and electricity are frequent. Organized calls for Black Land First, parties such as the Economic Freedom Fighters, and movements for decoloniality such as the student protests \#Rhodes Must Fall and \#Fees Must Fall have mushroomed in recent years. Human Rights Organizations and appointed and endless Commissions of Inquiry keep a close watch and wary eye on developments. In this failed mode of governmentality, and in the midst of oppositional politicking, neoliberalism has exploited productively the tensions between neofascism and Afropessemism.

Throughout this vortex of corruption, ever spiralling, liberal human rights discourses have increasingly become the arena on which the State is challenged but where the State also governs. 'Vulnerability', as governmentality and resistance is the technology through which the state governs and the modality through which those governed seek relief and find refuge. 
In this paper, we suggest, in like manner to others (Butler, 2004, 2010, Sabsay, 2016; Kulick and Rydstrom, 2015) that vulnerability, beyond its potentially devastating effect on souls and livelihoods, may also be a productive site for the articulation of alternative, and habitually silenced voices. However, this requires that we develop a notion of voice that goes beyond a framing in the liberal rights perspective, and that we attempt engagement with a different 'genre of the human' (Wynter, 2003). Thus, here, we introduce and further refine the idea of Linguistic Citizenship as an approach to agency and voice designed to draw attention to the power of the unheard and unattended voice, and one that opens to other discourses of the human. Linguistic Citizenship originally emerged out of a dissatisfaction with a politics of language built on affirmation/recognition and rights that effectively silences voices and erases agencies of those who are (a) not recognized as legitimate voices on regimented public arenas and, relatedly, (b) deemed not to be articulating voice in appropriate modalities of expression (genres, languages, etc) in ways that can be beard on political arenas. Since its inception, a number of applications of Linguistic Citizenship have been pursued. These have involved exploring forms of semiosis through which alternative voices are articulated - other registers of expressivity such as performance genres, and concomitantly other sites where a different/alternative notion of the political to a politics of recognition may be constituted. Widening the sites of the political has also meant widening the sphere of 'hearability', including 'listening between the lines' (for the unsaid, multiple possibilities and potentialities of interpretation layered into the spaces behind words), captured in a notion of the utopic, but also represented in a wider sphere of what constitutes a semiotics or discursivity of the political.

In what follows, we first engage with the theoretical grounding of Linguistic Citizenship as comprising agency and voice. In particular, we explore how a focus on acts of Linguistic Citizenship may orientate thinking on voice and agency to different sites of the body, as well as allow insight into the complex technologies and practices of vulnerability. We illustrate our reasoning on alternative voice by literally 'fleshing out' Linguistic Citizenship as it applies to the discursive 'surfacing' (Taylor, 2005) of 'body parts' with specific attention to South Africa. We conclude with a discussion laying out some of the more general implications for the political-discursive pursuit of alternative voices. 


\section{TALKING OF BODIES IN PARTS}

Bodies are made through talk, if not wholly, at least in part(s). This means that bodies are not just in or out of the world as 'entities uncoupled'; they are "not a site or surface but a process of materialization that stabilizes over time to produce effects of a boundary and surface we call matter" (Butler, 1993). Bodies are what are distilled out of relationships at different, scales, of 'surfacing (Taylor, 2005)', the practices, processes and discourses /representations ${ }^{11}$, which bring bodies and their parts and interiors into existence. Thus, the making of abused bodies is a long discursive process $-\mathrm{a}$ chain of signification through a mesh of relationalities. Indeed, it is the very permeability, the openness and vulnerability in relation with/ to others out of which bodies emerge, a "constitutive openness, in the subject, regardless of whether it is wanted or not" (Sabsay, 2016: 285).

In contemporary (neo)liberal society, vulnerability is the pre-eminent site of governmentality. The machinery of human rights, for example, is a powerful technology in the production of governable bodies through vulnerability. Sabsay (2016) notes how the institutional structures of liberal humanity and its politics 'humanitarianism and human rights serve to obscure this. She notes how crusades against clitoris circumcision (or prohibitions for European Muslim to wear the Burka (our example)) - ostensibly women's rights issues - are thinly veiled "civilizational crusades in the production of the racialized Other" (Sabsay, 2016: 281). In this respect, human rights discourses of vulnerability re-affirm (and keep firmly in place) rather than question or topple assigned injurability (Sabsay, 2016).

On the other hand, vulnerability as a preeminent site of control, means that it is here that the battle lines can be drawn, and a productive political resistance launched. If with the philosopher Hannah Arendt (1998), we take vulnerability as emerging out of a plurality of unpredictable and uncertain relationships, it is simultaneously the recognition accorded by this plurality of others that grounds individual voice and agency in a community. In other words, there should be "no contradiction between agency and vulnerability" (Sabsay, 2016: 285;) as the 'vulnerability [that] emerges from subjects' relationality is constitutive of action. However, we nevertheless need to ask what sort of agency? And what type of voice is recognized and heeded?

In an important sense, there is a contradiction in the liberal idea of voice and agency; this is that it requires that groups consent to be oppressed (and this is part of how vulnerability is constructed) - and to acknowledge particular, 'acceptable'

11. How bodies are represented determine what can be done with bodies. 
forms of oppression, namely through the reaffirmation of the diversity categories that pin oppression and continued subjugation (Sabsay, 2016). The categories of manufactured 'diversity' (race, ethnicity, sexuality, gender), which have been and remain grounds for historical and continued control and abuse of vulnerability (Sabsay, 2016: 231), are also the arenas on which abuse is contested, politically and otherwise. This means a continued representation of Self - affectively and discursively - in the voice of the hegemony. The liberal human rights framework thus treads a fine line between continuing the manufacture of 'abuse' - albeit in more palatable forms (for some) and a very limited construct of agency and voice that reinserts vulnerable and precarious groups into the very order that continues to subjugate them on the very grounds on which they are subjugated.

This reflects how 'voice' in liberal politics is that which has emerged over centuries out of the definition of the colonialized Other, that is, the black, female, language-less and heathen subject against the 'human' colonizer, the disembodied yet white, male 'master'. Thus voice has become disassociated from the body which hosts it, as liberal rights frameworks require a certain type of subject, one that is disembodied and abstract and universal. Only those voices that clearly echo those of MAN (the disembodied white male) are audible. The recognition that Arendt (with others) sees as a condition for voice and agency is only possible if that which needs to be recognized is recognisable in schemas of the Human/MAN form. In Wendy Brown's terms (1995: 106) "the subject is [...] ideally emancipated through its anointing as an abstract person, a formally free and equal human being, and is practically re-subordinated through this idealist disavowal of the material constituents of personhood".

In what way can the dispossessed and beaten give voice and exercise any agency for change, when, no matter how much voice and agency is accorded, it's always at the cost of what is worth voicing about in the first place, namely, the plight of the embodied Other? A number of authors have grappled with the question of where to find the voice of those made Other and to (re)think vulnerability as a productive political position (e.g. Diprose, 2013; Ziarek, 2013). The question is: how can we engage with voices whose 'material' constituents have been historically constituted as voiceless/as lacking voice and language (e.g. 'the native') without losing these voices in translation? Is there a voice beyond the assumed universal voice of 'rights'? Here, we offer Linguistic Citizenship as such an approach. Linguistic Citizenship refers to those practices, discourses and processes through which speakers strive for agency and voice in new and 'irregular' constituencies that fall outside of, or go beyond, the institutionalized and regimented, liberal, idea of communality/ 
sociality/citizenship. Studying modalities in acts of Linguistic Citizenship implies addressing how actors engage (semiotically) with the hegemony of institutionalized power through creating 'liveable' spaces ('in the nooks and crannies and cramped spaces' of institutionalized politics) for the production of discourses and practices of counter-hegemonic we-ness. These acts of Linguistic Citizenship of necessity involve other registers of voice and idioms of agency beyond those recognized or heard in a (neo) liberal politics ${ }^{12}$.

Linguistic Citizenship is at core is about the

the variety of semiotic means through which speakers express agency, voice and participation in an everyday politics (our italics) of language, and how non-mainstream speakers wrestle control from political institutions of the state by using their language over many modalities and giving new meaning and repurposing to reflect the social and political issues that affect them (Williams and Stroud, 2015).

Engaging with acts of Linguistic Citizenship means abandoning the idea of identity as one primary arena of political contest. This follows from a critique of a politics of recognition that works to affirm the palettes of 'regimented diversities' with which recognition works and through which harmful vulnerabilities are propagated (Stroud, 2001) ${ }^{13}$. It is also in this critical space that permeability, vulnerability, takes on a particular importance: that is, relinquishing or going beyond the certainties of established diversity categories and engaging with a plurality of possibilities for ontological refashioning of the self, is a risky and unsettling exercise. It is an exercise that demands a productive (and ethical) orientation to the vulnerability of Self and Other. However, perhaps of most interest in the context of governmentality through the body, Linguistic Citizenship offers the feasibility of engaging with a semiotics of the disassembled body, that is, with the material constitution of the body before it becomes a(n) (coherent) identity. In other words, seeking acts of citizenship in sites where bodies are constituted and contested outside of a politics of recognition (affirmation and identity) is to recognize that 'voice' and agency' may reside beyond or underneath the 'person' as corporeally defined.

12. In representing the various voices that surface in the vignettes that follow, we are acutely aware of the vagaries of researchers revoicing their subjects. In the South African context in particular, the complaint of who may legitimately voice whom remains highly contested and debated. This is a complex problem with which we struggle in this paper.

13. In the vignettes, it may appear that we are actually using the various categories of identity that we are attempting to go beyond in the analysis. However, when we refer to "black woman" or "young male initiate" or "white couples" we are not taking these categories as the analytical focus but merely using them as technical nomenclature, in order to go beyond, under, or within these categories by exploring the discourses of surfacing on body parts that subsequently become hidden/erased in conventional identity categories. 
In a similar fashion, Weheliye (2014) who despairs of finding voice and agency in a conception of the human as "full, self-present, and coberent subjects working against something or someone (2014: 2, our italics), suggests looking for voice in alternative genres of the human (Wynter, 2003). In particular, he suggests turning to "the manifold occurrences of freedom in zones of indistinction" (ibid: 2) where "we might come to a more layered and improvisatory understanding of extreme subjection if we do not decide in advance what forms its disfigurations should take on" (ibid: 2). He references Spiller's distinction between 'flesh' and 'body' where flesh is [..] "an alternate instantiation of humanity that does not rest on the mirage of Western man as the mirror image of human life as such (Weheliye, 2014:43) and thus outside of the tradition of political liberalism" (Brooks, 2020: 33).

Brooks (2020), in moves reminiscent of Linguistic Citizenship, proposes "a mode of fugitive listening that allows us to open our ears to the noisy voices and modes of speech that sound outside the locus of politics proper" (p. 25). Inspired by the work of Harney and Moten (2013) he situates a fugitive listening in 'the under-commons', "a space of polyphony and noise, a space that moves towards a collective understanding of subjectivity that is always already predicated on a collective relation (p. 36), that is "a radical reimagining of the traditional concept of the commons" (ibid).

We ask: what would it mean to literally flesh out voice, articulate the flesh, before it became lost in translation to a neoliberal, patriarchy and abstract corporeality (cf. Milani, 2018)? What does it mean to engage with the material conditions of personhood before they are discursively collocated as body - as a corporeality? What visceral dynamic of human agency can be found in disassembling the body as a coherent cerebral entity? What would it mean to engage ethically with the 'voice' of the flesh before it becomes the discursively constructed body of abuse with limited room to strategically manoeuvre? We attempt to address these questions through a linguistically-discursively mediated visceral politics of the flesh, that is, a conception of voice wrought by another idiom/genre of the 'human'. This involves relinquishing the idea of locating the idea of voice in coherent corporeality, and its articulation sourced out of categories of identity. Here, we explore the potential of body parts, in particular the multiple and competing manners of their surfacing (Taylor 2005), that is, the practices, processes and discursive regimes through which they appear in 'public' spheres. A focus on body parts, allows side-stepping or removing bodies from, large diversity narratives (race, woman, etc), that is, to elide the identity discourses that pervade and seal Other voices in diversity cages. 


\section{VIGNETTES OF VULNERABILITY}

Taking our point of departure in discourses and counter-discourses of vulnerable body parts, we present in this section seven short vignettes that illustrate a variety of ways in which individual body parts are entangled in, and attempt to dis/re-entangle themselves from, thick weaves of captured corporeality. We focus in particular on what languages, genres, multimodal expressions, repertoires 'surface' the part and become layered into the design of different parts, and how the parts can be said to counter-hegemonically engage with and speak back to practices and processes. As body surfacing serves to produce significant sites in broader orders and public spaces, we gain insights into what is at stake in contesting these orders when body parts are 'resemiotized'. In what follows, we present vignettes on vulnerable body parts of: the penis, the vagina, the breasts, the tongue, the ear, the skin, the phantom limb, and the face.

\subsection{Penile codes (Ndimphiwe Bontiya)}

In the South African Xhosa community, the first mark of manhood is the removal of the foreskin in a highly secretive ceremony reserved for initiated men and elders, and the immediate exclamation "Ndiyindoda" by the new initiate which means "I am a man". This is followed by weeks of isolation from the rest of the community, undergoing education of what it means to be a man (Mfecane, 2016). Mfecane notes that the initiate's "manhood is judged less by having a circumcised penis and more by his public conduct: dress code, responsibility, respect and avoidance of violence" (Mfecane, 2016, p. 207). In Taylor's terms, this is a surfacing of a body part; ostensibly signified by a surgical operation, but intricately embedded in inaccessible repertoires of the secret and sacred, conducted in landscapes carefully designed for the purpose, involving a spectrum of (male) participants, some of whom are spatially and temporally dislocated from the event (ancestors). The ceremony is of great importance for the social, economic and political life of what it means to be a man. However, it is also a hegemonic act of patriarchal, male, heterosexuality, where only one form of manhood is considered legitimate and acceptable; where the presence of black masculinity and male femininity coexisting in the secret initiation space is felt to be abhorrent and where alternative masculinities are (sometimes violently) silenced.

How do other subjectivities, other sexualities, find space to articulate in this context - if at all? A recent filmic depiction (InXeba) of a long term homosexual relationship between two male 'nurses', depicts how intimacy among men is 
multimodally created through: mutual 'silence' when the lovers engage in romantic or sexual encounters; the location of sexual acts between the two at a spatial distance (in thickets far from the camp, deserted houses) and temporally removed spaces (iconically marked by modernity in the form of pylons (far from traditional spaces). The use of isiXhosa is restricted to only speaking about topics in the distant past (for example, the childhoods) The articulation of homosexual intimacy through tropes of 'distance' and 'removal', linguistically, temporally, spatially and physically, literally crates a space beyond that circumscribed by the foreskin.

\section{$2.2 \mathrm{~B}(\mathrm{e})$ aring breasts (lost in translation) (Koki Kappa)}

On $4^{\text {th }}$ of October 2016, student protests took place on the campus of the University of Witwatersrand, one event in a succession of protests by \#RhodesMustFall and \#FeesMustFall protests. It was accompanied by not only a heavy police presence, but media, in the form of multiple news outlets. Some of the news outlets, such as $\mathrm{SABC}^{14}$ news, were livestreaming their coverage at the university. Students gathered in front of the Great Hall and eventually, clashed with the police. As tensions rose, fast approaching the rubicon, three Black women decided to intervene by staging a naked protest, within the protest (see Ndlovu, 2017 for an ethnographic account).

Nakedness is a part of protest repertoire and has a long history. From the stories of Lady Godiva, to the modern naked protests of groups such as FEMEN, from the pre-colonial naked protests across Africa, to the modern South African university students protesting against sexual assault ${ }^{15}$, nakedness has repeatedly been used as a tool in protest. It is worth noting that these protests are driven by women, demonstrating their understanding that nakedness is highly gendered, interpretations of naked female bodies are not the same as those of male bodies.

In order to understand what it means for Black women to protest naked, we need to refer to the social context of Black women and their bodies which is "inextricably linked to enslavement, hypervisibility, and other violent institutionalised epistemic projects" (Gqola, 2005: 3). Black women occupy a marginalised position as a result of colonialism and slavery, and in South Africa, apartheid. Importantly, the Black female body is also hypersexualized. The hypersexualisation of Africans was used as a justification for raping black slave women: they were "overly sexual, impossible to

14. The South African Broadcasting Corporation (SABC) is the national, public broadcaster in the country.

15. In April 2016, students at The University Currently Known as Rhodes held a naked protest in response to the released of a list of alleged rapists at UKCAR. Wits students held one in solidarity. 
satisfy and therefore impossible to rape" (Gqola, 2015:43). Other broad stereotypes include the Mammy: a sexless, caring older woman; and the Sapphire/Angry Black woman: a domineering, aggressive woman.

The naked protest began when three women, Hlengiwe Ndlovu, Lerato Motaung and Sarah Mokwebo, used their bodies to create a barrier between their fellow students and the police. They took their tops off, facing the police line and shouted "cease fire", telling the police to "stop shooting us" (SABC News, 2016). In addition, they had their crossed arms held over their heads, which was an additional physical index of surrender, depicting a posture linked interdiscursively to the images of the flesh of black slaves chained together, or chained to trees waiting for a whipping. In these postures and nakedness, there is a display of vulnerability, an extreme "openness to the other" (Petherbridge, 2016: 598) who may do them harm.

The act of bearing breasts was immediately effective - the police stopped firing and lowered their eyes in shame. A newspaper report described the reaction of the police as:

uncomfortable... the officers' fingers rest beside their triggers. The indecision is visible. As the women get closer, the officers lower their guns, averting their eyes from the half-naked activists..., their eyes looking everywhere except at the topless protesters, even as they hurl insults and demand acknowledgement (Whittles, 2016).

This was a 'carnal/fleshy' spectrality of the moment - manifested as intuitive reading of the bared flesh and a deep, instinctive recognition of its significance. This is a perfect example of flesh creating a communion, a new sociality. As with the Penile Code, the police momentarily stepped outside of the here and now (of the protest space), resemiotizing the space as one of 'fleshy' communion built on shared 'shame' and its significance. The police engaged with vulnerability and shame in accordance with the social script. However, this was not the only 'surfacing' of the body-part. The media, on the other hand, attempted to defuse the significance of the protest by (re)signifying the meaning of bare breasts in more officialised, institutional discourses and patriarchal discourses, re-shaming the women with comments such as "when a breast is shown let it be a tennis (ball). People are showing breasts and those breasts are droopy. They're like wet All Stars without shoelaces." (Mbangeni, 2016). In a police briefing following the protest, the then Acting National Police Commissioner Kgomotso Phahlane said

When those students took off their clothes was that not public indecency? Is public indecency not an offence? It is within our mandate. Where are their parents? We must call them to order. (African News Agency, 2016) 
The bearing of breasts is subsequently reinserted into the dominant discourse of the day. We describe something similar at play in the following vignette.

\subsection{Reclaiming the vagina (Shanleigh Roux)}

Vagina Varsity is an online course for women in 16 sessions of 23 minutes that ostensibly seeks to strengthen women's self-confidence with respect to the intimacies and realities of the vagina. In the on-line (Youtube) series, a variety of multimodal and multilingual means are deployed to 'tease out' how vaginal vulnerability is constructed (in a patriarchical context) in order to be dismantled as such. Subsequently, the (exposed) vulnerability is (supposedly) productively remediated in the service of a new more confident self. The rationale of the campaign is the desire to remove the stigma of vagina and its fluids that has resulted in women neglecting to learn about everyday vaginal care, causing "embarrassment, shame, myths and even healthcare problems that women then feel too shy to discuss with anyone" (Makhele, 2016). The Vagina Varsity campaign sought thus to "empower... and educate...women and girls to speak about their bodies" (SABC Digital News, 2016).

In two out of the total of six Vagina Varsity lessons, the campaign draws on an intriguing pop-up straw man representing all of the conceivable stereotypes about vaginas. It is a white male, Southern-sounding American figure, staged as an antagonist against the rights of the vagina, rolling his eyes, shouting insults and behaving in a decidedly sarcastic and contemptuous fashion. The session on 'Vaginal discharge' is entitled 'Honourable Discharge' with a clear Bakhtinian sidelong glance to the military bearing of the (tired and re-tired) old man at the same time as it elevates the status of the (vaginal) discharge.

When the two show hosts, Thembe and Nwabisa, talk about vaginal discharge, his comments range from chauvinistic arrogance ("nothing should come out of woman's vagina apart from a baby") to downright insults ("women's vaginas smell like fish"!). Here we find semiotised the stereotype of a vaginal anti-rights critic: the Southern USA drawl indexes him as a patriarchical, anti-feminist; the way he is represented multimodally, allows us to easily infer that he is also likely antiabolitionist, a landed slave gentry, and cruel to animals and people alike. As with 'Penile Code', the vaginal vulnerability felt by women is semiotically repackaged through tropes of temporal distancing (mouthed by the historical figure of the old man, seated on a horse, wearing a coat and tails) and spatial dislocation (Southern USA, saloon music in the background, racially White) expressed in the language and dress and multimodal framing of the old man. The two show hosts kin dialogue with each other 
engage with the old man, countering his claims and insults, and do so in a colloquial and status diminishing language (e.g. "Dude, whoa! You have got to dial it back"). His comments are ridiculed and treated with irony, as shown in the vivid facial expressions of the two presenters when they counter his claims. Young viewers are addressed directly and in familiar and vernacular language, and are encouraged to replace their use of euphemisms to refer to the 'vagina' with the term 'vagina' and more scientific sounding phraseology such as: ovulation, "ring of elastic and folded mucous tissue", "corona" and "sufficiently lubricated and aroused". The message conveyed in the segment is that what this old man says should have no bearing on the lives and happiness of modern women. On the contrary, modern women, we are told by the presenters, need to embrace their vagina.

The semiotics of vaginal repackaging in the show replaces an intimate although taboo register of terms referring to the vagina, into a more public and commercial genre. Instead of a local, social vulnerability, vaginal discharge is transformed into a transnational dilemma for which, 'fortuitously', easily accessible commercial help is packaged and ready. As with much body-oriented mediatisation, the module plays on, and actively builds and reinforces, women's perceived vulnerability and sensitivity to their bodies, in order to ostensibly address this vulnerability. At the same time, it pitches the sale of dedicated products for vaginal hygiene. In other words, we see a hegemonic, neoliberal genre of appropriation of intimacies: capitalizing on the privacy and intimacy of registers of the vagina. The intimacy of the flesh and its registers are replaced, as we saw to be the case for some of the discourse surfacing of beared breasts.

\subsection{The deafening tones of time. Or structural whiteness as tinnitus (Amiena Peck, Janine Harrry)}

Two young Black women are about to leave an upmarket restaurant in a historically white beach area of Cape Town when they meet a white couple in the doorway on their way into the restaurant. It is late. The two couples exchange initial pleasantries. As the encounter is re-told by Thandi, one of the black girls, the white couple then proceed to initiate a longer exchange, asking with apparent concern how the girls had planned to get home. They were ostensibly worried about the potential vulnerability of the women who they assumed would need to find their way 'back to the township' and at the very late hour (transport in Cape Town is notoriously unreliable). The assumption was that the girls did indeed reside in such an area. The girls had attempted to re-assure them that the Benz standing at the curb side was theirs and that they would be safe travelling home. The white couple 
clearly found it difficult to believe the girls' claim that the Benz did in fact belong to them and not to, (what the girls assumed what was 'in all likelihood, the white couple's belief) their 'pimp'. As the narrative progresses, it becomes increasingly clear that the white couple and the black women are engaging in two very different 'conversations' - or, better, in two distinct modes of listening and speaking. Whereas the white couple can be heard (or may intend) to express care for their vulnerability, Thandi hears the multivocal chimes of structural whiteness, and the understated positioning of blacks as trespassers. The overarching structuring of the interaction for the White couple is a dominant discourse that constructs the black female body as sex workers, reliant on males for financial and mobile support. The Black girls' presence in the prestigious, once historically 'whites'-only space of Big Bay was then understandable as the girls having accompanied a sugar daddy or boyfriend. Of course, the location of the interaction was an important scenic prop in the context: even though apartheid signage such has been removed from the linguistic landscape of South Africa, we see how these very apartheid discourses, specifically the Group Areas Act of 1950 have become handed-down discourses which are materialized and (re)produced. There is thus a sense in which the old materialities of apartheid have been internalized - and zombified (cf. Bock and Stroud, 2018), to rise again as new lives in encounters of this type. What Thandi hears is the White couple ventriloquating the voice of privileged structural whiteness.

In narrating this story, Thandi offers a counter-hegemonic gesture throughout by inserting a highly indexical marker of Pan-African Blackness, untypical for her everyday speech, namely the rolled, tremulant $/ \mathrm{r} /$. Her affective stance is one of rejection.

What we see narrated here is the interactional accomplishment of racialized vulnerability across encounters of difference, where decades/centuries of structural whiteness create a condition of 'white deafness' on behalf of the white couple and black audibility to historical injustice on behalf of the black women. As with the previous vignettes, we find a chronotopical (space-time) play in the articulation of vulnerability.

\subsection{The paralysed tongue. (Quentin Williams and Jaclisse Mayoma)}

In today's South Africa, xenophobic discourses targeting non-South African Black Africans emerge on the public scene with distressing frequency every number of years. To be a migrant is to be forever vulnerable. In particular, young adolescent migrants, the most vulnerable of migrants, are not only at a crucial point of their lives as emerging young adults, but often also experience turbulence, fracture, and 
trauma through the migrant experience itself. On the other hand, the liminality of migrancy offers opportunities to fashion new senses of self. One issue confronting young migrants from DRC is an inherited translocal politics of cultural authenticity pertaining to the French language: When among their fellow Congolese (who many times immigrated as older migrants), the younger migrants often find themselves 'rejected' because of the supposed poor quality of their French. The new arrivals are made to feel anxious and vulnerable for not being a legitimate speaker of 'proper French' because they learnt to speak French at home with their parents as opposed to having formally learnt French through extensive exposure in the Congolese school system, "so it's not the same..." Here speaking "clean French" is seen as more privileged and authentic. The incapability to speak this 'clean French' is then linked to stereotypes of unintelligibility, and to the noise of the 'barbarian' the kwerekwere - a term used in South Africa for other African foreigners who do not belong, who are intruders. Ultimately, they come to understand that the way they speak French will only elicit negative social judgements with deleterious effects on peer group acceptance. As with Fanon's Black Skin, White Masks (1952 [2008]), they are caught up in words and trip over their tongues. The way beyond the stiffness and clumsiness of their tongues is to cultivate a flexible tongue by acrobatic skate-boarding across language forms. They do this by cultivating a 'youth multilingualism', (Williams, 2016), that is 'the playful and didactic intermixing of everyday multilingual practices and events as a way to (re) invent themselves and alternative futures in both online and offline spaces'. 'Youth Multilingualism' is not just about practices and events of multilingualism, it is also about how young multilingual speakers talk about multilingualism and language; "about how established forms of speech permeate their lives amidst ideological tensions, both in urban and rural spaces" (op cit: 4). They thus escape failing rigours of the cultivated tongue by designing nifty and acrobatic moves of their own.

\subsection{The phantom limb (Jason Richardson)}

Like the prior tongue caught in strictures of authenticity, and the vagina given a supposedly more palatable 'sheen', some disabled youth also feel their vulnerability has been hijacked and tied to, or sewn, into webs of language in ways that silence. The following excerpt is from a narrative (elicited in interview) by a young learner in a school for the disabled. She is attempting to explain the circumstances surrounding another young learner who had previously had a fit in class: 


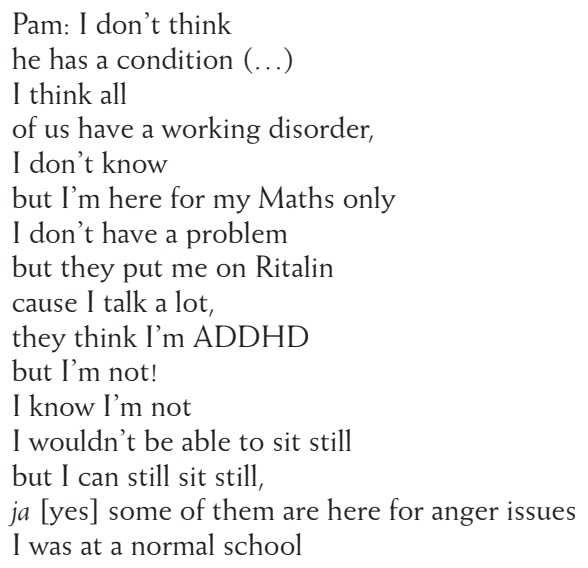

Pam is here explaining what she is "not" in a context of labels and discourses of perceived deficiency - of lack. She makes the point that "I'm here for my Maths only". What we see Pam doing is literally escaping, slipping out of, her entanglement in all the words that imprison her and define her vulnerability. Unable to engage in other ways, she removes herself from her prison cell of uncertainty, creating a position from which not to speak. As with the Penile Code, agency and voice find expression in silence.

\subsection{Faces (Sibonile Mpendukana)}

In creating "the West," the European Renaissance shaped a global geography of imagination that required a "Savage slot", a space for the inherently Other" (Trouilliot 2003: 1). The West and its vulnerable Other is recreated each time participants meet across a research project. However, for the indigenous researcher, the research process constructs also the Self as Other, and a potentially silenced, or refashioned voice in structures of Western epistemology. "Academic disciplines do not create their fields of significance, they only legitimize particular organizations of meaning. They filter and rank and in that sense, they truly discipline - contested arguments and themes that often precede them" (Trouillot, 2003: 9). Research disciplines the researcher, as much as, or more, than anybody else. There are dilemmas in 'an Other' studying 'Others' whom they are historically and materially bound with? One such is the ambiguity and uncertainty, the need to build bridges between discomfort and comfort, between struggle and familiarity that the researcherOther comes face-to-face with. The plight of the indigenous people/researchers is to grapple with "the disconnections that are apparent between the demands of 
research, on one side, and the realities they encounter amongst their own....with whom they share lifelong relationships, on the other side" (Tuhiwai Smith 1999: 5). In Southern contexts - more so than in many other contexts - the researcher, in other words, is in some respect both the subject of inquiry and the producer of the research. The lines are blurred because of sharing common experiences and a history of power and subordination with the researched. This moves the researcher beyond self-positioning to a more complex arena of moving between two identities, a researcher and one of the participants. This duality does not only give rise to an ambiguity of role in the psyche of the researcher which requires overcoming, but also gives rise to another dilemma, faced head-on less often. This pertains to the problems attendant on the fact that the Others are denied speaking because "...their speaking lacks appearance. It is not transformed into speech" (Gordon, 2011: 100). According to Gordon, the erasure of speech implies the erasure of the conditions of speech. That is, it denies "appearance such as gestural sites and the constellation of muscles that facilitates speech-namely, the face". (2011: 100). What, then, of the very face of the researcher-Other - is that Face denied surfacing? Is the researcher-Other not always engaged therefore in a battle of life or death? Is research itself not a space of vulnerability.

\section{DISCUSSION}

We have looked into what it means when (vulnerable) bodies are constituted as such, and if there is anything in their making that can lead to their unmaking? We focused in particular on the discursive, semiotic, making and unmaking, noting how body parts are generative of many registers and stories. The stories have served to pry open some of the workings of the flesh and its articulations. Because body parts are variously 'surfaced' (Taylor, 2005) in different semiotic registers and genres (multilingual and multimodal), their articulations are constitutive of different acts of Linguistic Citizenship. Finally, because bodies give rise to/are the topic of discourse, processes and practices on public arenas, they clearly are imbricated in important sociopolitical processes, are sites of resistance, comprising points around which new, alternative subjectivities and socialities, can congeal or be contested.

We have explored the variety of hegemonic and counter-hegemonic processes, practices and discourses whereby body parts surface as public, political parts. Such unregulated (at times) indecipherable senses/modalities disturb and unsettle the sensibilities of ears and eyes attuned to seek less 'disarticulated' meanings, in less multivocal or polypohonic encasements. These are interruptive 
genres and modalities (cf. Williams and Stroud, 2015; Stroud and Williams, 2017; Stroud, 2018; Flockemann, forthcoming). Linguistic citizenship, then, is how the plurality of (alternative) voices form new constituencies in new sites, opening up for new meaning potentials. In keeping with the critique of identity categories, as well as the evidence from the vignettes, this plurality of voices does not necessarily emanate from a coherent corporeal 'identity'. Linguistic Citizenship is in this respect a 'dis-assembling' tool. In fact, relocating voice (and agency) beyond the 'coherent and bounded body' to (in this case) body parts allows for openings to new regimes of discourse. We see, for example, how the vagina is a site for both patriarchal regimented and neoliberal discourses, as well as more culturally embedded and specific surfacings. In Penile codes, other silent spaces on the margins of language offer an intimacy and 'agency' otherwise not possible to attain. This is a different conception of plurality as a condition for agency and voice - the plurality of the parts (sexual organs, ears, faces, skin colours) and the plurality of competing discourses through which they are articulated to a complex, interwoven new sociality of the Self. In some respect, it is the complex of competing discourses and practices of surfacing of different fleshy parts that create the synergetic sense of personhood, of subjectivity (and its felt tensions and contradictions).

Linguistic Citizenship is predicated on engaging with voices outside of neoliberal/capitalist structures. The examples here offer one way in which we might harness 'the potential of vulnerability and the politics of the body in a discourse-representational and antagonistic, radical democratic politics, that goes beyond neoliberal capitalism' (cf. also Sabsay, 2016: 279). We suggest by way of discussion that Linguistic Citizenship can offer the broader discursive spaces in which biotechnical power can be redirected to counter harmful political and discursive hegemonies.

\subsection{The appendix (all autbors)}

A final body part that we can live without but that we all share and have in common is the appendix which has its own set of discourses and registers. It is therefore fitting, we feel, to gather all our voices in one last surfacing of the part in a joint reflection on Linguistic Citizenship as a whole.

Chris and Quentin: when we were putting the body part surfacings together, we started thinking of Linguistic Citizenship as a process of chronotopical structuring - imaginative or evocative re-co-ordinations. In many of the cases we see here, 'voices' become audible out of subjectivities as imagined (enacted) in other times and other places. 
Amiena and Janine: We felt that something in need of further discussion is an idea of Linguistic Citizenship as not only 'vocalizations' in the 'interstices' and 'in-between spaces', but also as a manner of 'listening' and 'speaking' in-between. The white couple need to listen beyond their words in order to lay bare their own vulnerability as a productive space to engage with blackness beyond structural whiteness. Similarly, there is an opportunity for black women to unlearn the mode of listening-without-responding, a learned submissive behaviour which appears to be collectively lodged in the ears of many previously disadvantaged people.

Sibonile: Of course, for any utterance there are a multitude of different potential 'readings'. "I see a resonance here with Linguistic Citizenship as methodology: De Souza Santos emphasizes how "...epistemologies of the South call for establishing bridges between comfort and discomfort zones, between the familiar and unfamiliar, the strange fields of domination and of struggle" (Santos 2018: 142). This requires "visibility to other libraries and other knowledges" (Santos 2018), that privileges a multiplicity of knowing and voice-ings of different vantage points (the force field of 'agency' for Arendt, for example - plurality and natality). It involves the researcher (as well as the participant) in dealing with complexity, uncertainty and ambiguity, and a cultivation of the ability of listening beyond or between what is 'conventionally said', or of being able to engage with other repertoires of accounting and narrative (cf. Veronelli, 2016, 2017, on the coloniality of language). It involves engaging with the methodological implications of Linguistic Citizenship that recognizes that what is meant has more significance than what is ostensibly said, and that much of what is said resides in the cramped spaces, the margins, the 'undercommons' of Harney and Moten (2013) or the alternative sociality of Fanon, Mbembe.

Jason: 'From my study, I see how our agencies are somehow situated in silent spaces that have somehow been overlooked by, or been muffled, those voices of vulnerability that would attempt to capture selves under identity labels. The entanglement in words, the need for 'escape' in Pam's case is so resonant with Ndimphiwe's penile situation. The operative moment in Ndim's and case is 'escape' - creating other spaces, shifting the time and space coordinates (at least in the imagination, cf. also Vagina Varsity - literally re-temporalizing and re-spatializing the taboo to Southern States of America in the 1800s).

Janine and Quentin: In our case, 'escape' to imposed voices is through youth multilingualism and acrobatic hybridity to off-set the stiff tongue. Rather than 
a complete relocation out of language, it is a negotiation, a criss-crossing between languages that open for agency and voice.

Ndimphiwe: Different body parts linked to different languages including trauma/ silence - that couch competing hegemonies.

Koki: We note then how the breast is 'surfaced' in at least 3 distinct - shame, patriarchal body shaming and in judicial/legislative terms, and in different public spaces. The force of the act is in the uptake, and it is only in the actual moment of bearing the breasts that the act is a momentary act of Linguistic Citizenship that succeeds in shifting the unfolding of the event outside of the normative script of violent retaliation. As with the Vagina, we note the hegemony of particular corporeal surfacings - reading the 'body' rather than listening to the flesh in the different mediatization of public spaces

\section{CONCLUSION}

In this paper, we have tried to capture the productivity of vulnerability as a site of political contestation by focusing on vulnerabilities arising out of practices and discourses of body-part 'surfacing'. This has involved tracing how forms of vulnerability are semiotically constituted out of the pluriversality and multivocality of everyday engagements, and explored how individuals and groups made vulnerable enact and 'counteract/contest' vulnerability across modalities (multilingual/multimodal) in acts of Linguistic Citizenship. Linguistic Citizenship turns the vulnerability that oppresses into a productive space for a discursive politics of voice and agency, albeit in other forms and manifestations than the liberal. Vulnerability opens to hearing resonances that disturb; it "opens us to new possibilities of existence" (Diprose, 2013). It is here where the possibilities for a discursive, counter-hegemonic politics (where language formulations/new genres important) can be formulated through vulnerability as a productive mechanism of the plural.

\section{REFERENCES}

AFRICAN NEWS AGENCY. (2016, 4 October). Police against naked protest, call for maximum restraint. The Citizen. https://citizen.co.za/news/south-africa/1305150/ police-against-naked-protest-call-for-maximum-restraint/ 
ARENDT, H. (1998). The Human Condition. Chicago: University of Chicago Press.

BOCK, Z.; STROUD, C. (2018). Zombi landscapes: representations of apartheid in the discourses of young South Africans. In A. Peck, Q. Williams and C. Stroud (eds) People in Place: Making Sense of Linguistic Landscapes. London: Bloomsbury.

BROOKS, A. (2020). Fugitive listenings: Sounds from the Undercommons. Theory, Culture and Society, v. 37, n. 6, p. $25-45$.

BROWN, W. (1995). States of Injury: Power and Freedom in Late Modernity. Princeton: Princeton University Press.

BUTLER, J. (1993). Bodies that Matter: On the Discursive Limits of "Sex". New York: Routledge.

BUTLER, J. (2004). Precarious Life: The Powers of Mourning and Violence. London: Verso Press.

BUTLER, J. (2010). Frames of War: When is Life Grievable? London: Verso.

DIPROSE, R. (2013). Corporeal Interdependence: From Vulnerability to Dwelling in Ethical Community SubStance, v. 42, n. 3, p. 185-204.

FANON, F. (1952 [2008]). Black Skin, White Masks. New York: Grove Press.

FLOCKEMANN, M. (forthcoming). Affect, Performance and Language: Implications for an Embodied and Interventionist Pedagogy. In Bock, Z and Stroud, C. (eds.). (forthcoming). Language and Decoloniality in Higher Education: reclaiming voices from the South. London: Bloomsbury Press.

GORDON, L. (2015). What Fanon Said: a philosopbical introduction to bis life and thought. Fordham University Press.

GQOLA, P. D. (2005). Yindaba kaban'u'ba ndilahl'umlenze? Sexuality and Body Image: Guest Editor, Pumla Dineo Gqola, introduces the issue. Agenda 19(63), 3-9.

GQOLA, P. (2015). Rape: a South African nightmare. Johannesburg: Jacana Media.

HARNEY, S.; MOTEN, F. (2013). The Undercommons: Fugitive Planning and Black Study. 1-165. Research Collection Lee Kong Chian School of Business. Available at: https://ink.library.smu.edu.sg/lkcsb_research/5025

KULICK, D.; RYDSTROM, J. (2015). Loneliness and its opposite: sex, disability, and the etbics of engagement. Durham and London: Duke University Press. 
MAKHELE, T. 2016. SA Launches World's First Vagina Varsity. Retrieved November 30, 2016, from https://citizen.co.za/lifestyle/fitness-and-health-your-life-your-life/1328824/ sa-launches-worlds-first-vagina-varsity/

MBANGENI, L. (2016). 'Don't mock breasts that saved us from rubber bullets'. Independent Online (IOL).

MFECANE, S. (2016). "Ndiyindodoa" [I am a man]: theorising Xhosa masculinity. Antbropology Southern Africa, v. 39, n. 3, p. 204-214.

MILANI, T. (2018). Is the rectum a goldmine? Queer theory, consumer masculinities, and capital pleasures. BAKER, P.; BALIRANO, G. (eds). Queering Masculinities in Language and Culture. pp. 19-42. Basingstoke: Palgrave and Macmillan.

NDLOVU, M. W. (2018). \#FeesMustFall and Youth Mobilisation in South Africa: Reform or Resolution? London: Routledge.

PETHERBRIDGE, D. (2016). What's Critical about Vulnerability? Rethinking interdependence, recognition and power. Hypatia, v. 31, n. 3, p. 589-605.

SABC Digital News. (2016, 31 October). Avri Spilka on the World's first Vagina Varsity [Video File]. Retrieved from https://www.youtube.com/watch?v=vUUgkF93phw

SABSAY, L. (2016). 'Permeable bodies': Vulnerability, affective powers, hegemony. In BUTLER, J.; GAMBETTI, Z.; SABSAY, L. (eds.). Vulnerability in resistance. Duke University Press.

SANTOS, B. (2018). The End of Cognitive Empire: the coming age of epistemologies of the South. Durham and London: Duke University Press.

STROUD, C. (2001). African mother-tongue programmes and the politics of language: Linguistic citizenship versus linguistic human rights. Journal of Multilingual and Multicultural Development, v. 22, p. 4, p. 339-355.

STROUD, C. (2018). Linguistic Citizenship. In LIM, L.; STROUD, C.; WEE, Lionel (eds). The Multilingual Citizen. Towards a Politics of Language for Agency and Change. pp. 17-39. Bristol: Multilingual Matters.

STROUD, C.; Williams, Q. E. (2017). Multilingualism as Utopia: Fashioning Non-Racial Selves. AILA Review, v. 30, p. 165-186.

TAYLOR, J. (2005). Surfacing the body interior. Annual Review of Antbropology, v. 14, p. 741-56. 
TIHIWAI SMITH, L. (1999). Decolonizing Methodologies: Research and Indigenous Peoples. London: Zed Books.

TROUILLOT, M. (2003). Global Transformations: Antbropology and the modern world. Palgrave Macmillan: New York.

VERONELLI, G. (2015). The Coloniality of Language: Race, Expressivity, Power, and the Darker Side of Modernity. Waguda, v. 13, p. 108-134.

VERONELLI, G. (2016). A Coalitional Approach to Theorizing Decolonial Communication. Hypatia, v. 31, n. 2, p. 401-520.

WEHELIYE, A. (2014). Habeas Viscus: Racializing Assemblages, Biopolitics and Black Feminist Theories of the Human. Durham, NC: Duke University Press.

WHITTLES, G. (2016). How brute force yielded to naked resistance. Mail \& Guardian.

WILliAMS, Q. (2016). Youth Multilingualism in South Africa's Hip-Hop Culture: a metapragmatic analysis. Sociolinguistic Studies, v. 10, n. 1, p. 109-133.

WILLIAMS, Q.; STROUD, C. (2017). Linguistic Citizenship: language and politics in postnational modernities. In Milani, T. Language and Citizenship: Broadening the agenda pp. 89-112. Amsterdam: Johns Benjamins Publishing Company.

WYNTER, S. (2003). Unsettling the Coloniality of Being/Power/Truth/Freedom: Toward the Human after Man, its Overrepresentation - An Argument. CR: The New Centennial Review, v. 3, n. 3, p. 257-337.

ZIAREK, E. P. (2013). Feminist Reflections on Vulnerability: Disrespect, Obligation, Action. SubStance, v. 42, n. 3, p. 67-84.

Recebido: $24 / 11 / 2020$

Aceito: 11/12/2020

Publicado: 14/12/2020 